\title{
Determination of High Temperature Corrosion Rates of Steam Boiler Evaporators Using Continuous Measurements of Flue Gas Composition and Neural Networks
}

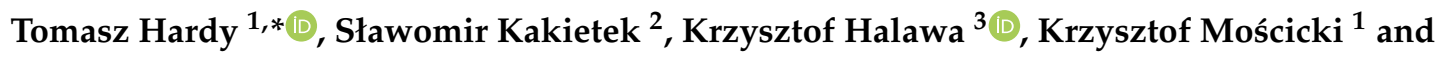 \\ Tomasz Janda 4 \\ 1 Department of Mechanics, Machines, Devices and Energy Processes, Wroclaw University of Science and \\ Technology, Wybrzeże Wyspiańskiego 27, 50-370 Wrocław, Poland; krzysztof.moscicki@pwr.edu.pl \\ 2 Thermal Processes Department, Institute of Power Engineering, Augustówka 36 Street, \\ 02-981 Warsaw, Poland; slawomir.kakietek@ien.com.pl \\ 3 Department of Computer Engineering, Wroclaw University of Science and Technology, Wybrzeże \\ Wyspiańskiego 27, 50-370 Wrocław, Poland; krzysztof.halawa@pwr.edu.pl \\ 4 PGE Energia Ciepła S.A., Ciepłownicza 1 Street, 31-587 Kraków, Poland; Tomasz_Janda@gkpge.pl \\ * Correspondence: tomasz.hardy@pwr.edu.pl; Tel.: +48-71-3202049
}

Received: 9 May 2020; Accepted: 13 June 2020; Published: 17 June 2020

\begin{abstract}
The use of low-emission combustion techniques in pulverized coal-fired (PC) boilers are usually associated with the formation of a reduced-gas atmosphere near evaporator walls. This increases the risk of high temperature (low oxygen) corrosion processes in coal-fired boilers. The identification of the dynamics and the locations of these processes, and minimizing negative consequences are essential for power plant operation. This paper presents the diagnostic system for determining corrosion risks, based on continuous measurements of flue gas composition in the boundary layer of the combustion chamber, and artificial intelligence techniques. Experience from the implementation of these measurements on the OP-230 hard coal-fired boiler, to identify the corrosion hazard of one of the evaporator walls, has been thoroughly described. The results obtained indicate that the continuous controlling of the concentrations of $\mathrm{O}_{2}$ and $\mathrm{CO}$ near the water wall, in combination with the use of neural networks, allows for the forecasting of the corrosion rate of the evaporator. The correlation between flue gas composition and corrosion rate has been demonstrated. At the same time, the analysis of the possibilities of significantly simplifying the measurement system by using neural networks was carried out.
\end{abstract}

Keywords: steam boiler; high-temperature corrosion; online monitoring; neural networks

\section{Introduction}

Very strict $\mathrm{NO}_{\mathrm{x}}$ emission regulations, rising prices in the European Union emissions trading system (EU ETS) and in general zero emission EU policy in energy production forces fossil power plants to adapt markedly the technology and asks for the increased flexibility of large utility units. In the case of solid pulverized fuel combustion, the reduction in $\mathrm{NO}_{\mathrm{x}}$ emissions with a simultaneous increase in economic efficiency forces different low-emission combustion techniques to be implemented. The latter requirement, in correlation with different power demands changing during the day, intensifies the high-temperature corrosion processes of evaporator walls. The issue stated above also greatly negatively affects the reliability of the boiler and the operating availability of the power unit.

The high-temperature corrosion process in steam boilers is a very complex phenomenon, briefly described in [1-3]. The main key factors in low oxygen corrosion in pulverized fired utility boilers 
are the sulphur, chlorine, phosphor, alkaline salt, and halide contents in fuel, which are directly responsible for corrosion in highly substoichiometric regions. Theoretically, corrosion may be at least partially avoided by an adequate selection of fuels or even the mixing of fuels $[4,5]$. This, however, is only one of the parameters of fuel selection, among others like e.g. price, and usually is not taken into account. Additionally, in the case of lignite-fired power plants, there is almost no possibility to influence fuel quality. Thus, in many cases there is a need to find other solutions to decrease the risk of corrosion. One of them involves covering the tubes by a special layer, protecting them from corrosion [6,7]. This method, however, is very often not economical and its utilization is found mainly in waste incineration or biomass plants. Another method involves determining the high risk areas of corrosion by the modelling of ash deposition by computational fluid dynamics (CFD) [8,9]. The results of such CFD modelling can be used to either cover these areas with protective coatings, introduce additional air nozzles, protecting walls from highly concentrated flue gas compounds and slag/ash deposition, or change, in general, the combustion process performance (air flows, burners modification, etc.) $[10,11]$. However, despite such sophisticated software and methods, there is a need to control the corrosion risks on-line and predict potential failure or corrosion rate.

Corrosion rate might be delivered by periodic measurements of the thicknesses of the tubes. These measurements, however, are very lengthy, require the boiler to be shut down, cleaned and, as stated above, they are carried out periodically - usually once per one or two years. There is experience in the construction and use of corrosion probes, based on various on-line measurement techniques, such as electrical resistance (ER), electrochemical current noise (ECN), linear polarization resistance, or probes with replaceable corrosion coupons [4,12-16]. Tests using corrosion probes are interesting in terms of testing the corrosion behavior and the impact on the corrosion rate of selected factors, such as the change in fuel composition. However, such solutions are troublesome, as long-term applications and many months of tests can easily be lost as a result of damage to the measuring probe. In [17] water wall wastage in a pulverized coal boiler, the corrosion rates were investigated using experimental data in conjunction with CFD.

In practice, [18] some empirical correlations between corrosion rate, $\mathrm{CO}$ concentration, and temperature were shown. Thus, very often, corrosion risk may be determined by the measurement of $\mathrm{O}_{2}, \mathrm{CO}$, and sometimes the temperature in the boundary layer of the evaporators. However, these measurements are usually carried out once every one or two years. There is a need to build a system that allows $\mathrm{O}_{2}$ and $\mathrm{CO}$ concentration to be measured on-line to continuously define areas with a high risk of corrosion and also to provide countermeasures by adequate changes in air or fuel flows. Moreover, such a system should directly determine the on-line corrosion rate. Economic analyses indicate the benefits arising from the use of simple methods of corrosion protection, such as protective air curtains in conjunction with the continuous monitoring of the furnace wall boundary layer [19].

For the efficient optimization of the combustion process, it is advisable to develop and use non-intrusive measuring techniques (e.g., to control the temperature changes, radiative properties of flame, or measurements of selected exhaust components) [20,21]. Such measuring techniques allow real-time gas analysis directly within the process. Especially in combustion conditions chambers where reductive atmospheres are very common, the frequency of gas sampling can be crucial for the correct determination of $\mathrm{CO}$ and $\mathrm{O}_{2}$ concentration. However, such solutions are expensive and difficult to implement within the main combustion zone of a PC boiler, where there is a high temperature, high moisture content, high concentration of ash in the flue gas, and an intensive slagging process. The costs of using such methods are high, in particular when the entire walls of the furnace chamber should be covered by the measuring system, which involves the implementation of local measurements at many points, simultaneously. During the normal operation of the PC boiler, changes of its performance or capacity do not occur very quickly. Therefore, in the context of long-term measurements of gas composition in the boundary layer, there is no need to use measurement methods giving results in real-time, and a slight delay in recording measurement results is acceptable. In this case, it seems reasonable to use the available and tested measurement techniques used for characterizing local 
combustion conditions by monitoring gas concentration (e.g., $\mathrm{O}_{2}, \mathrm{CO}$, and other components) [22,23]. To reduce the costs of measurements covering all of the furnace walls, it is worth taking additional measures to reduce the number of measuring points, while maintaining the possibility of the correct interpretation of the results.

For the last two decades, artificial neural networks (ANNs) have been successfully used to represent many processes with complex physics and chemistry. In particular, their fault tolerance for noisy data (typical of boiler data), their abilities to learn from examples, and their generalization properties, have provided great potential in many application areas related to complex combustion processes [24]. They have been used successfully in diverse applications, ranging from modelling coal/biomass devolatilization [25] or rate of char oxidation [26], through predicting quality of fuel blends [27] to predicting the emissions of dioxins from waste power plants [28], identifying slagging in the vicinity of burners [29], or soot-blowing optimization [30]. ANNs were also used to predict the corrosion behavior of metal alloys [31], corrosion fatigue crack growth rates [32], or the atmospheric corrosion behavior of steel and zinc [33]. However, they are mostly focused on particular process phenomena rather than evaluating the corrosion danger, especially low oxygen corrosion in utility boilers. There are also some known works related to ANN utilization for recognizing or finding the compositions of gas mixtures [34,35]. However, none of them (except preliminary authors' papers [36]) were used for predicting $\mathrm{O}_{2}$ and $\mathrm{CO}$ concentrations in the area near the evaporator walls of a steam boiler to forecast the threat of high-temperature corrosion.

\section{OP230 Boiler as an Object of Research}

The high-temperature corrosion of evaporators in utility pulverized fired boilers is the adverse phenomenon caused by low emission technologies. It is very important to diagnose corrosion risks in the boiler, since it may cause unplanned and long outages of the boilers. The method of the online monitoring of high-temperature corrosion risks in steam boilers is elaborated, based on the continuous measurement of $\mathrm{O}_{2}$ and $\mathrm{CO}$ concentration in flue gases in the boundary layer of the evaporator $[19,37]$. The main idea of this method is to determine the high reductive zones with a low level of $\mathrm{O}_{2}$ and a high level of $\mathrm{CO}$ concentration, which can be presented as (current or averaged in the given period) maps of corrosion risk [38]. This information can be directly used by operators or DCS systems to optimize air or fuel flows to the boiler to avoid such zones [39].

The tested OP230 boiler is a tangentially fired hard-coal boiler with natural circulation and a nominal live steam capacity of $230 \mathrm{Mg} / \mathrm{h}$ under pressure $13.6 \mathrm{MPa}$, as shown in Table 1, and it is combined with a $50 \mathrm{MW}$ turbine. Three ball mills supply the fuel to three levels of jet burners where the highest level connects to mill no. 1, while mill no. 3 connects to lowest level of burners. At low capacity, the boiler is powered by two mills operating in variable configurations.

Table 1. The OP230 boiler main operational parameters.

\begin{tabular}{cc}
\hline Parameter & Value and Unit \\
\hline Drum pressure & $15.0 \mathrm{MPa}$ \\
Live steam mass flow rate & $230 \mathrm{t} / \mathrm{h}$ \\
Live steam pressure & $13.6 \mathrm{MPa}$ \\
Live steam temperature & $540^{\circ} \mathrm{C}$ \\
Feed water pressure & $16.4 \mathrm{MPa}$ \\
Feed water temperature & $205^{\circ} \mathrm{C}$ \\
Hot air temperature & $255^{\circ} \mathrm{C}$ \\
\hline
\end{tabular}

Currently, the acceptable level of NOx emissions is maintained through the use of low-emission combustion, mainly the advanced OFA (over-fire air), ROFA (rotating opposed fired air system), air staging, and SNCR (selective non-catalytic reduction) methods. The main role in reducing $\mathrm{NO}_{\mathrm{x}}$ emissions is played by the primary methods that keep $\mathrm{NO}_{\mathrm{x}}$ emissions as low as possible. In the 
main burner zone, the average air excess coefficient is maintained at the level of 0.90-1.05. The upper level of the burners is at $15.9 \mathrm{~m}$, while ROFA air is fed at $20 \mathrm{~m}$ and $23 \mathrm{~m}$ (on the right and left wall). Reducing the airflow in the combustion zone results in the formation of a reducing atmosphere (with substoichiometric air) in a substantial part of the combustion chamber, which is also affected by the configuration of the working burners and boiler capacity. Besides, the frequent changes in boiler efficiency and changes in the configuration of the working mills (and the related work of the burners), contribute to frequent changes in the composition of flue gas near the water walls. Locally, high corrosion rates in this boiler have been observed in recent years that have caused evaporator failure. Such failures always bring measurable financial losses due to the lack of energy production and the need for quick repairs. Therefore, it is advisable to take action aimed at limiting the risk of failure.

It is obvious that many factors, such as fuel composition (including $\mathrm{Cl}, \mathrm{S})[1,3,40]$, stoichiometry, flue gas composition (e.g., $\mathrm{CO}, \mathrm{H}_{2} \mathrm{~S}, \mathrm{HCl}, \mathrm{SO}_{2}$ ) [41,42], and the chemical composition of ash deposits on the tube surfaces [1,3,42-45], play a significant role in the high-temperature corrosion process. Moreover, the corrosion history from the period of long term boiler operation may impact the present corrosion rate [46]. The experiences of the authors and other researchers show that the measurement of $\mathrm{O}_{2}$ and $\mathrm{CO}$ near the water wall can be a good indicator of corrosion risk assessment for a given boiler and its fuel $[19,23]$. Therefore, a lot of research was carried out regarding the implementation of the monitoring of the gas atmosphere near the combustion chamber walls. One such system has been developed and tested in the OP-230 boiler [38,47]. This system uses a continuous on-site measurement of the $\mathrm{O}_{2}$ and $\mathrm{CO}$ concentrations in the layer near the wall of the boiler chamber walls, and enables the identification of a reductive atmosphere and may be useful for preventing intensified corrosion.

The use of the continuous monitoring of the flue gas composition in the area near the evaporator walls for indicating the presence of a reductive atmosphere seems to be an easy and cost-effective solution. With such system boiler can be operated with continuous optimization of the combustion process by making adequate adjustments in air or fuel stream distribution. A decrease in reducing zones number or level of $\mathrm{CO}$ and thus the diminishment of the corrosion rate can be achieved. Figure 1 shows the location of the measuring points (no. 1-26) for the periodic measurements of the exhaust gas composition using portable gas analyzers (Testo 350), while the red circles indicate the points where the continuous measurements were carried out (S1-S5). The flue gas was sampled for 5 min (with stream approximately $1 \mathrm{~L} / \mathrm{min}$ ) from a layer close to the surface of the evaporator wall, and the measured $\mathrm{O}_{2}$ and $\mathrm{CO}$ values were averaged. Then, the measuring tracks were cyclically blown with compressed air for $10 \mathrm{~min}$ (due to the need to clean them). Therefore, the results were recorded in the system with a frequency of $15 \mathrm{~min}$. For this reason, the measurement can be called quasi-continuous.

The electronic transducers and software used in the measuring system have been specially developed and built for this purpose, while the other components are available on the market, such as $\mathrm{O}_{2}$ zirconia sensors (Bosch LSM11), CO sensors (CF40000 Membrapor/CO-GP-40-5 GRI Instrument), and $\mathrm{H}_{2} \mathrm{~S}$ sensors (3HLM CiTicel). The oxygen concentration was measured directly on the boiler wall at points $\mathrm{S} 1-\mathrm{S} 5$, while the $\mathrm{CO}$ and $\mathrm{H}_{2} \mathrm{~S}$ concentrations were measured in the control cabinet (serving the entire wall) to which the exhaust gas from the S1-S5 connectors was sucked, as shown in Figure 2. The concentration of $\mathrm{H}_{2} \mathrm{~S}$ was measured on-site at only one point to test for a correlation with $\mathrm{O}_{2}$ and CO. Examples of continuous measurements of the $\mathrm{O}_{2}$ and $\mathrm{CO}$ concentrations in the boundary layer at the two selected points on the font wall of the OP-230 boiler-nos. S2 and S3 in Figure 1-are shown in Figure 3. 


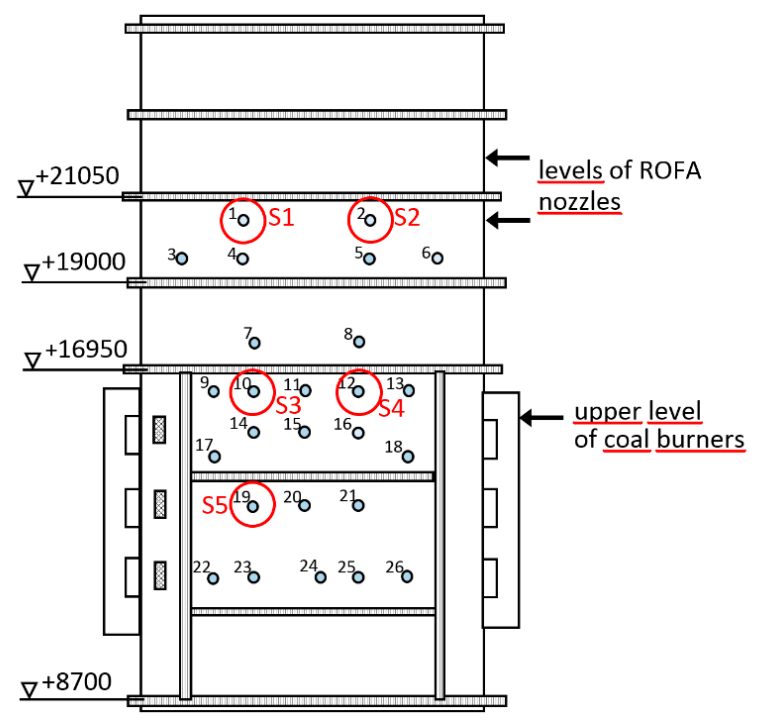

Figure 1. View of location points for measuring the flue gas composition in the boundary layer of the OP230 boiler.

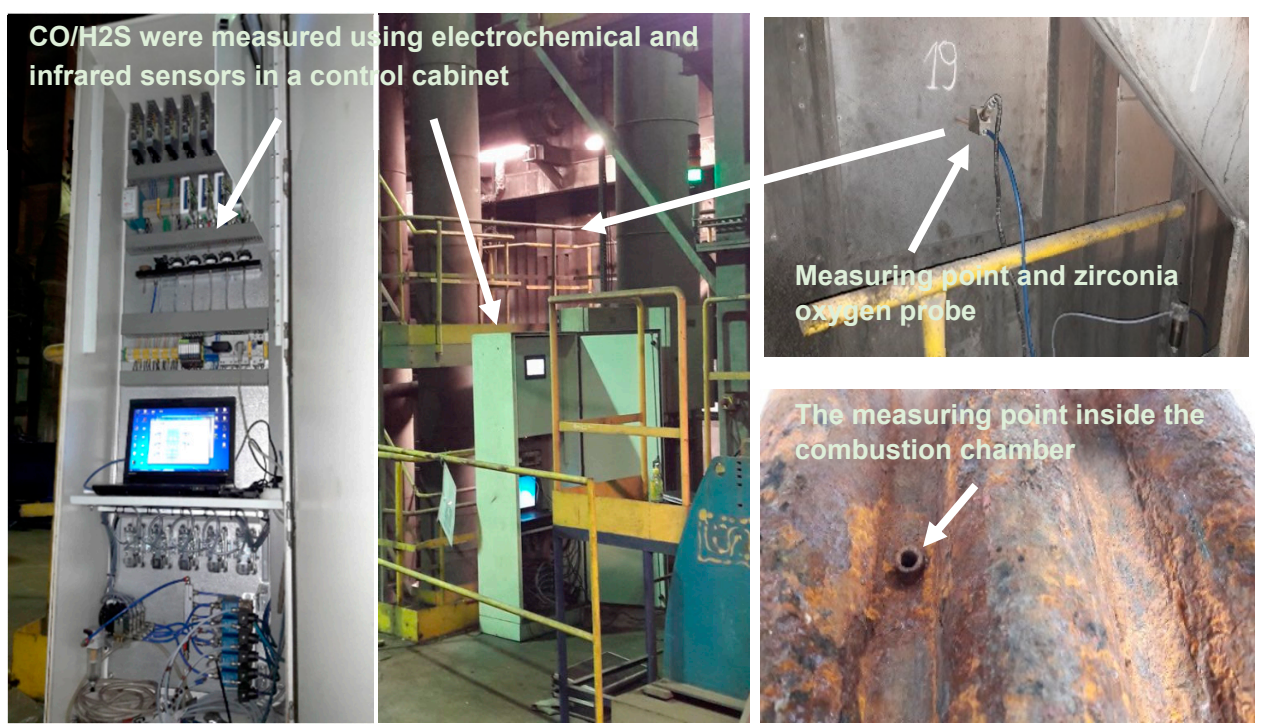

Figure 2. View of the measuring system (measuring point and control cabinet) covering the front wall of the OP-230 boiler.

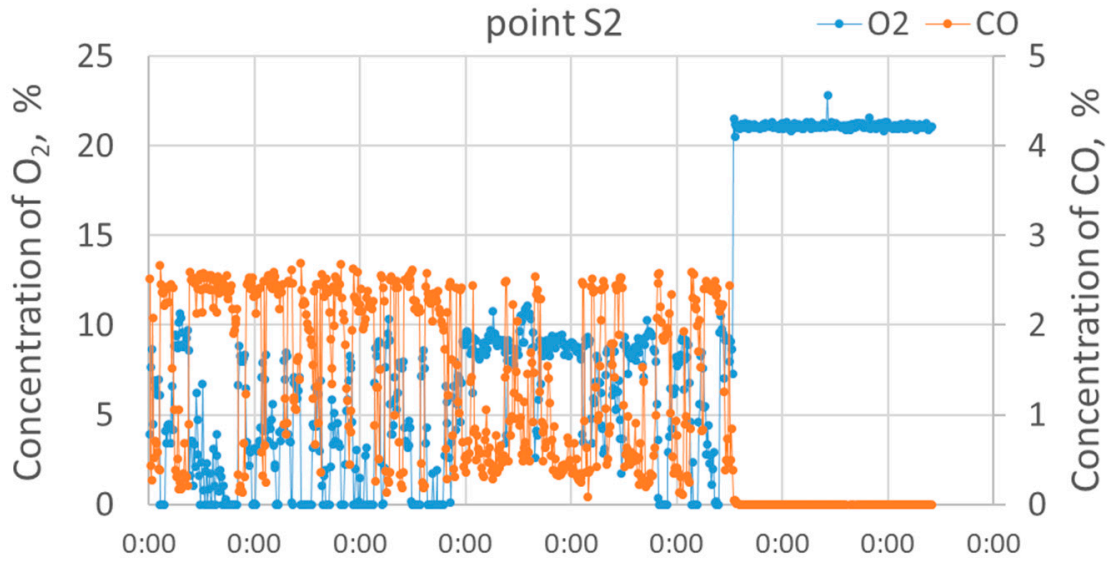

(a)

Figure 3. Cont. 


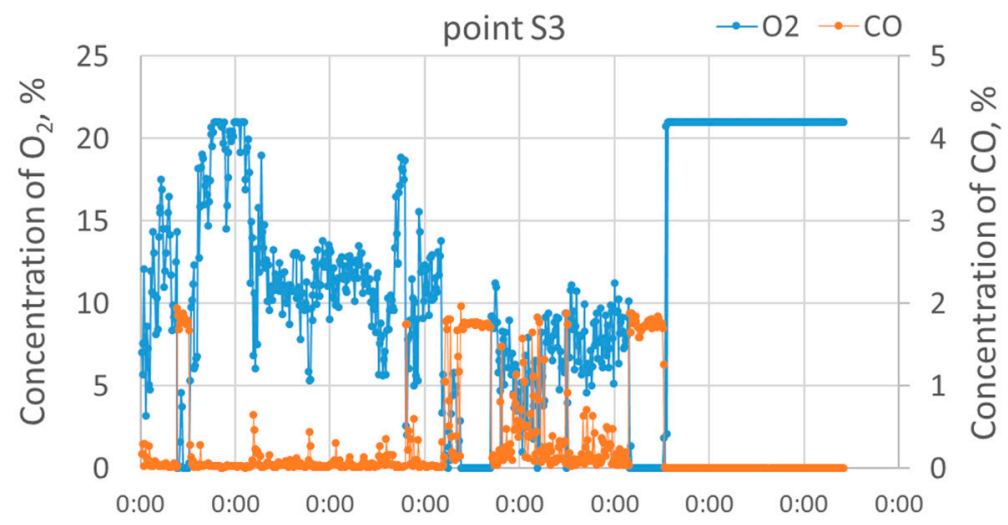

(b)

Figure 3. Examples of continuous measurements of $\mathrm{O}_{2}$ and $\mathrm{CO}$ concentrations in the boundary layer at S2 and S3 measuring points ((a,b), respectively) for one week (data recorded every $15 \mathrm{~min})$.

\section{Application of Neural Networks to Estimate the Rate of Corrosion at OP-230 Boiler}

There are many different types of artificial neural network (ANN). Typically, an ANN is made up of some number of interconnected processing elements, called neurons, linked together by connections with weights. An ANN is a "black box" with inputs and outputs. The most important part of the ANN performance is the learning phase, which can be understood as the process of updating the connection weights and, sometimes, network structure as a response to a set of training data, obtained usually from experimental measurements. The overall behavior and functionality of an ANN depend on the network architecture, activation function, learning methods, and training set quality. No high computing power is needed for the operation of the neural network used. Among the different types of ANNs, the Feed-Forward Multilayer Perceptron (MLP) network, presented in Figure 4a, is the most popular supervised-learning network and has found application across many disciplines, also in the presented work. It is particularly suited for use in tasks involving the prediction and classification of complex data. A MLP network is typically organized in a series of layers made up of a number of interconnected neurons, each of which contains a transfer function $f$, as shown in Figure $4 \mathrm{~b}$. Input data are first presented to the network via the input layer, which then communicates these data via a system of weighted connections to one or more hidden layers, where the actual neuron processing is carried out. The response of the hidden layers is then transferred to an output layer where the network outputs are computed. During the training phase, as shown in Figure 4, these outputs are compared with the known desired values of the given process. Arising errors from the difference between the predicted and known values are back-propagated through the network and used to update the weights and biases of all the connections. The process is successively repeated until the errors fall below the given threshold. At this stage, the network training is complete. However, it should be appreciated that training is not necessarily a one-off procedure, since the network can learn and be updated on-line if the system or process changes. The most widely used transfer functions for the neurons are tanh, sigmoid, rectified linear unit, or linear function, and are shown in Figure 5. In current work, the tanh function was used (where tanh denotes hyperbolic tangent). 


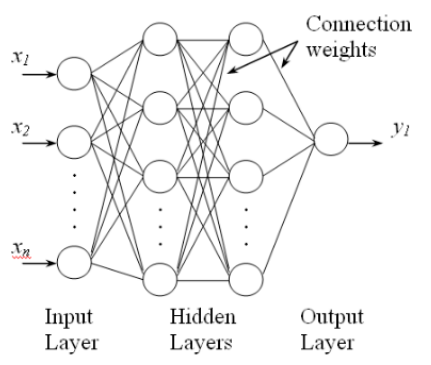

(a)

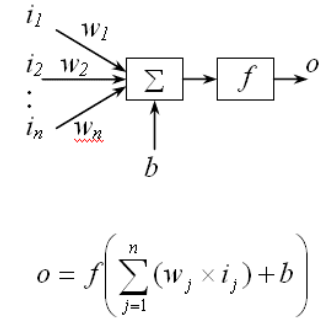

(b)

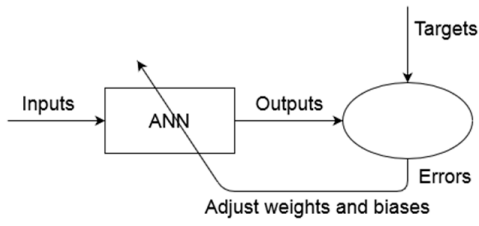

(c)

Figure 4. (a) Typical ANN architecture, (b) Computational Model of a Single Neuron, (c) ANN training process.
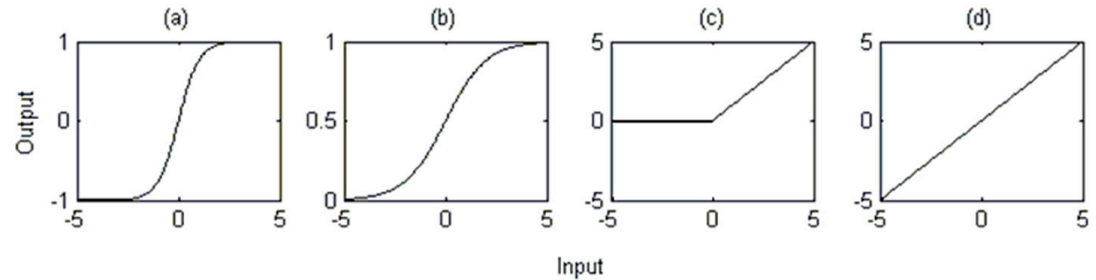

Figure 5. Neuron Transfer Functions: (a) 'Tanh' (b) 'Sigmoid' (c) 'ReLU' and (d) 'Linear'.

For error estimation, the mean square percentage error (MSPE) was used:

$$
M S P E=\frac{\sum_{i=1}^{n}\left(d d_{i}-d t_{i}\right)^{2}}{n} \cdot 100
$$

where $d d_{i}$ is normalized expected value (real value), $d t_{i}$ is normalized estimated by ANN value, $n$ is the number of samples. As the inputs to ANN all measured $\mathrm{O}_{2}$ concentrations through $\mathrm{O}_{2}$ sensors, were used -5 inputs. The outputs were $\mathrm{O}_{2}$ and $\mathrm{CO}$ concentrations in other measuring points where developed $\mathrm{O}_{2}$ sensors were no placed (for clarification see Figure 1). The value of the threshold in training the back-propagation algorithm was varied depending on the selected point, usually between 0.1 and 0.01 .

Figure 6 shows the results of the ANN training and testing for $\mathrm{O}_{2}$ and $\mathrm{CO}$ predictions. In general, the results of the ANN performance are, in most cases acceptable. However, there are some higher deviations for several points, in particular, where high standard deviations during measurements of $\mathrm{O}_{2}$ and CO occurred (training data), which also caused relatively high MSPE error. However, training was carried out for only eight cases, and testing for only two. Thus, the obtained ANN performances should be assumed as a success. Better predictions were found by authors in other own similar investigations performed on other boilers [36,48], where more training and testing cases were available.

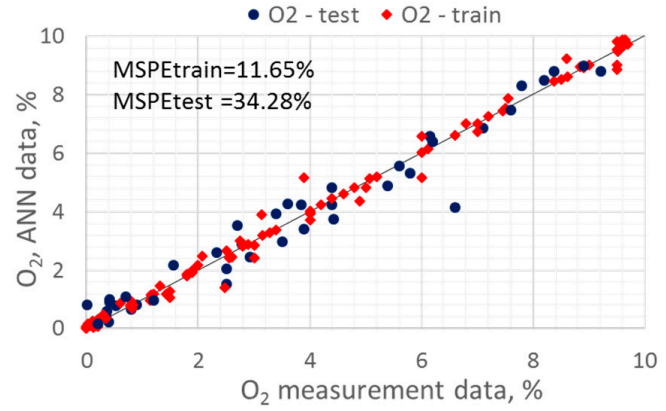

(a)

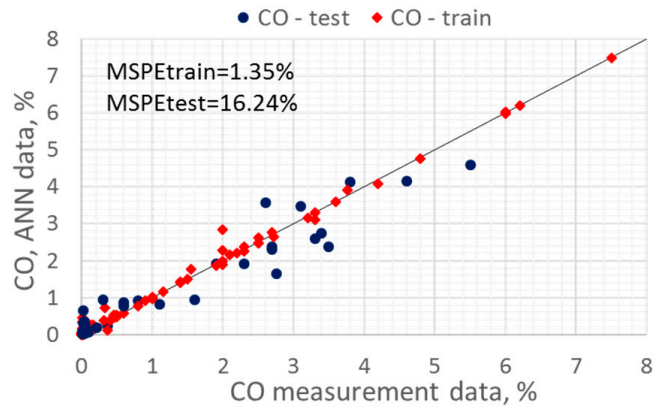

(b)

Figure 6. ANN results for training (red) and testing (blue) for $\mathrm{O}_{2}$ and $\mathrm{CO}$ concentration predictions $((\mathbf{a}, \mathbf{b})$, respectively); solid lines for man eye. 
The criteria for the degree of corrosion risk were selected based on literature data and the authors' own experiences. In Table 2, the degree of corrosion risk (from none to very high) is marked with appropriate colors that correspond to the colors of the maps showing the degree of corrosion hazard generated in the Rachel software, [36,38].

Table 2. The assumed criteria for danger of low-emission corrosion estimation $\left(\mathrm{O}_{2}\right.$ and $\mathrm{CO}$ in \%).

\begin{tabular}{cccccc} 
None & Very Low & Low & Medium & High & Very High \\
$\mathrm{O}_{2} \geq 5$ & $4 \leq \mathrm{O}_{2}<5$ and & $3 \leq \mathrm{O}_{2}<4$ and & $3 \leq \mathrm{O}_{2}<5$ and & $1 \leq \mathrm{O}_{2}<2$ and & $\mathrm{O}_{2}<1$ and \\
& $0.2 \leq \mathrm{CO}<3$ & $0.2 \leq \mathrm{CO}<3$ & $\mathrm{CO} \geq 3$ & $0.5 \leq \mathrm{CO}<1$ & $\mathrm{CO} \geq 0.5$ \\
\hline $3 \leq \mathrm{O}_{2}<5$ and & $2 \leq \mathrm{O}_{2}<3$ and & $1 \leq \mathrm{O}_{2}<2$ and & $1 \leq \mathrm{O}_{2}<2$ and & $\mathrm{O}_{2}<1$ and & $1 \leq \mathrm{O}_{2}<2$ and \\
$\mathrm{CO}<0.2$ & $\mathrm{CO}<0.2$ & $\mathrm{CO}<0.2$ & $0.2 \leq \mathrm{CO}<0.5$ & $0.2 \leq \mathrm{CO}<0.5$ & $\mathrm{CO} \geq 1$ \\
\hline \multicolumn{5}{c}{$\mathrm{O}_{2}<1$ and } & $2 \leq \mathrm{O}_{2}<3$ and \\
\hline \multicolumn{5}{c}{$2 \leq \mathrm{O}_{2}<3$ and } \\
$0.2 \leq \mathrm{CO}<3$ \\
\hline
\end{tabular}

\section{Results and Discussions}

To elaborate on this corrosion rate, the data from the high-temperature corrosion monitoring system, operated in the OP-230 hard coal-fired boiler were used against typical ultrasonic thickness measurements of the evaporator wall tubes. The concentration values of $\mathrm{O}_{2}$ and $\mathrm{CO}$ in the boundary layer were collected for six months of boiler operation, whilst wall thickness measurements were carried out in 2014 and 2017 (in 280 and 315 points on the wall, respectively). Moreover, artificial neural networks were used to determine the $\mathrm{O}_{2}$ and $\mathrm{CO}$ gas species concentrations in the boundary layer of the whole wall of the boiler evaporator, based on five $\mathrm{O}_{2}$ sensor indications. Typical feed-forward neural networks with one hidden layer with 8-10 neurons and tanh activation functions were used with a back-propagation training algorithm.

\subsection{Determination of Corrosion Rate in the Tested Boilers}

The map of change of evaporator thickness over time was drawn up based on measurements made by ultrasonic technique during the boiler outages in April 2014 and in February 2017. Over almost three years boiler operation (including downtime caused by breakdowns and renovation) loss of tube thickness on the front wall reached over $2 \mathrm{~mm}$ at selected points, which gives the even rate of 0.6-0.7 $\mathrm{mm}$ per year, as shown in Figure 7. The water wall tube thickness was compared at 280 points on the front wall between levels $11.2 \mathrm{~m}$ and $21.2 \mathrm{~m}$.

The power unit worked $17,566 \mathrm{~h}$ during this period. For $40 \%$ of this period (of working hours), it ran with electric power in the range of 42-52 MW, but the average power of the unit in the analyzed time period was about $39 \mathrm{MW}$. Figure 8 presents changes in the electric power of the unit (which corresponds to boiler capacity) during eighteen months of operation.

Frequent changes in capacity, the configuration of operating burner systems, and frequent boiler outages mean that the average values of the oxygen concentration in the boundary layer recorded online are slightly higher than during the short and periodic measurements carried out using portable flue gas analyzers under steady conditions. The continuous measurements also included short-term boiler operation periods, with higher air excess in the burner zone during the configuration changes of working mills. 


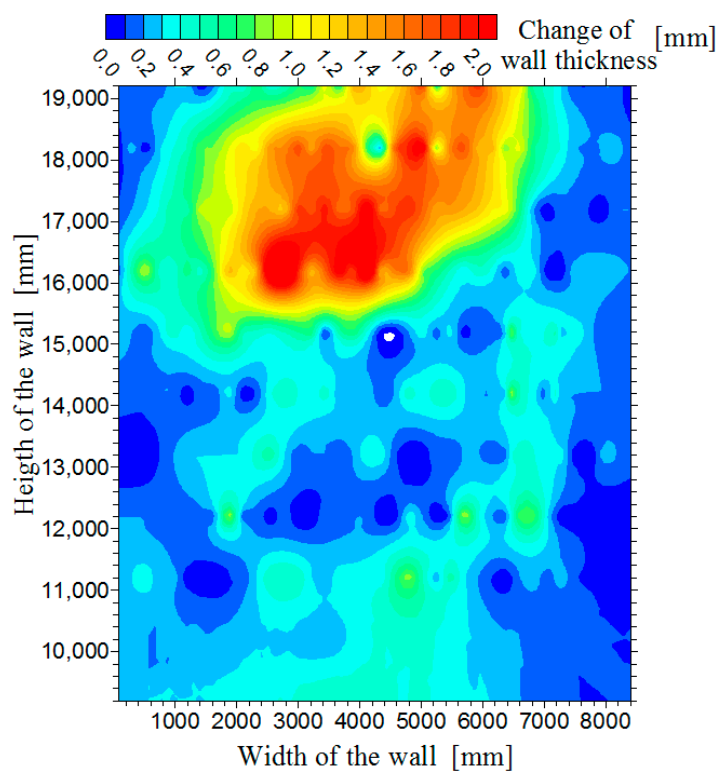

Figure 7. Changes in evaporator tube thickness, determined based on periodic measurements (in 2014 and 2017) by ultrasonic technique. Reprint with permission [38].

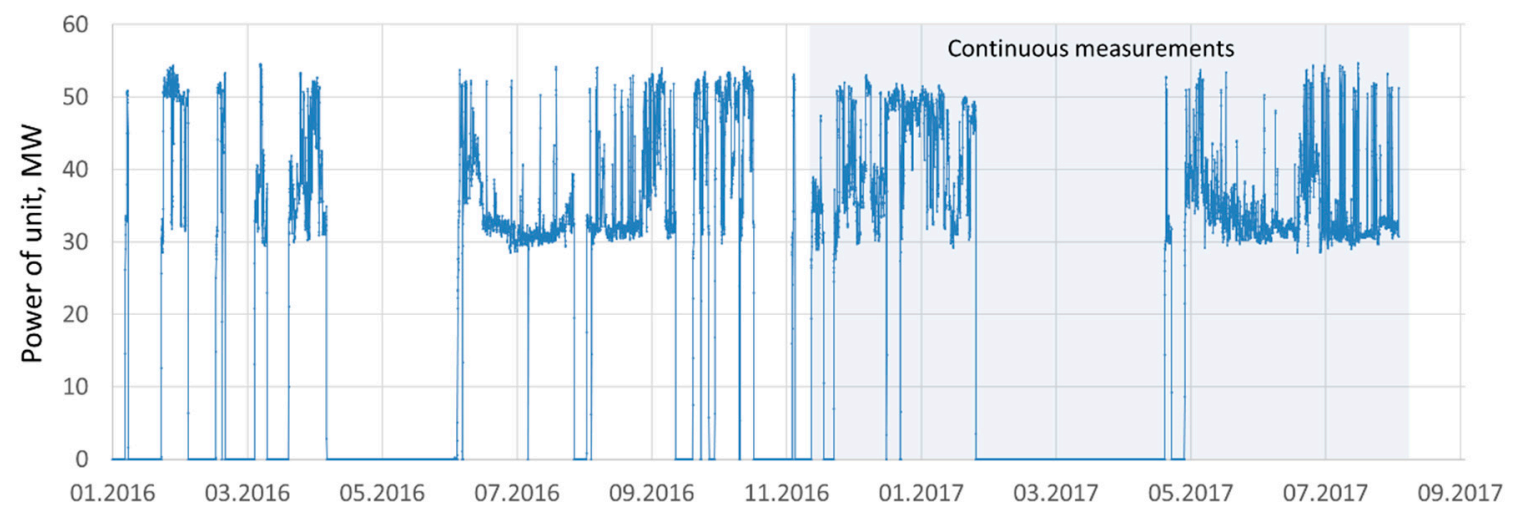

Figure 8. The electric power of the unit during the eighteen month operation period (which correlates with changes in boiler capacity). The dark background color indicates the period when $\mathrm{O}_{2}$ and $\mathrm{CO}$ measurements were recorded.

\subsection{Monitoring the Corrosion Hazard of the Evaporator Wall}

\subsubsection{Periodic Measurements of the Flue Gas Composition near the Wall of the Combustion Chamber}

Measurements of the exhaust gas composition in the boundary layer on the front wall of the boiler were made for several variants of the boiler with a working system of secondary air ROFA. Variants of the boiler differed in power, the configuration of the working mills, and air discharge. The number of measurement variants was limited since the work of the unit was not tampered with, and measurements were performed only for the conditions existing on a given day.

At 26 available measuring points on the front wall, the concentrations of $\mathrm{O}_{2}$ and $\mathrm{CO}$ were measured. These data were used to study the neural networks in Rachel software. For some boiler operational parameter variants, additional components of the exhaust gas were measured, mainly to determine their correlation with the concentrations of $\mathrm{CO}$ and $\mathrm{O}_{2}$. Such measurements have to answer to whether it is worth taking other exhaust components, apart from or together with $\mathrm{CO}$ as reliable indicators of the occurrence of a reducing atmosphere. For example, Figure 9 shows the difference in $\mathrm{O}_{2}$ and $\mathrm{CO}$ concentrations in the layer near the front water wall at different boiler operating parameters. As can be seen, the area in which the reduction zone occurs promotes faster corrosion changes as the boiler 
operating conditions change. In the initial testing period, other exhaust gas components, such as $\mathrm{H}_{2} \mathrm{~S}$, were also measured, but due to the clear correlation between $\mathrm{H}_{2} \mathrm{~S}$ and $\mathrm{CO}$, as shown in Figure 10, it was abandoned to simplify the measurement system and make it cheaper [38].

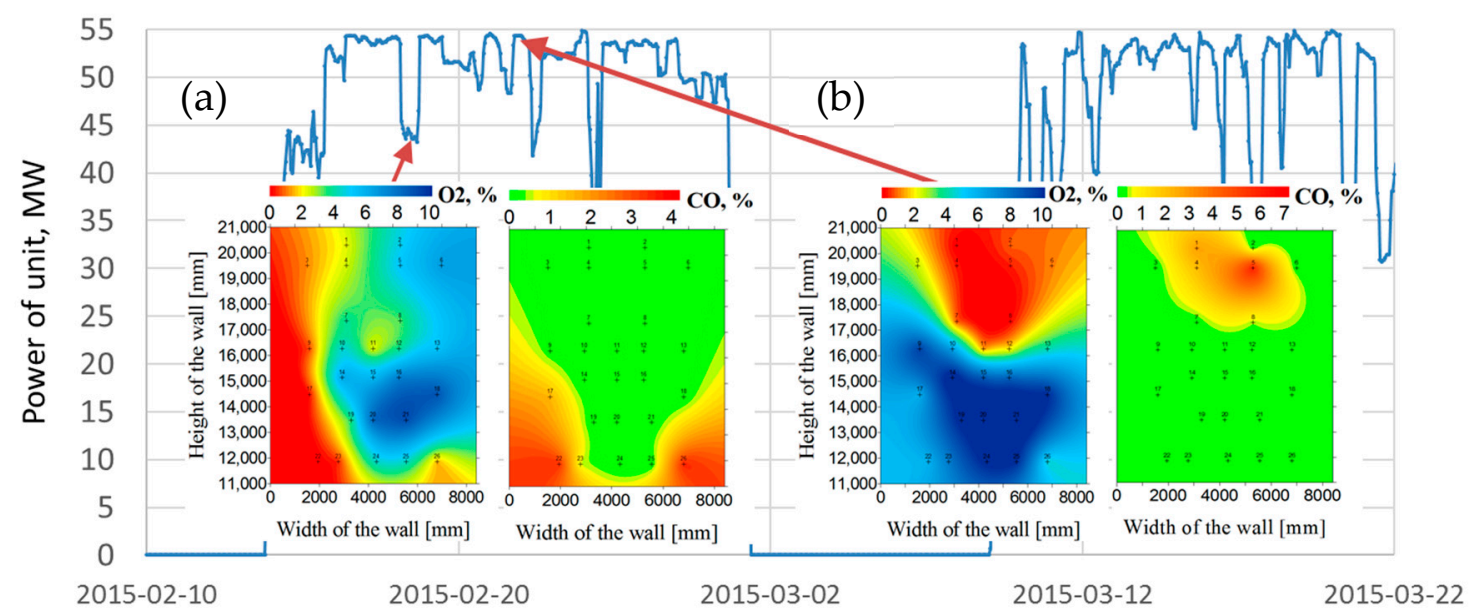

Figure 9. Changes in the electric power of the block and examples of $\mathrm{O}_{2}$ and $\mathrm{CO}$ concentrations near the front wall for two different boiler operation variants ((a)-44MW, (b)-53MW). The scale of the maps is from 0 to $10 \%$ for $\mathrm{O}_{2}$ and from 0 to $4 \%$ for $\mathrm{CO}$, respectively.

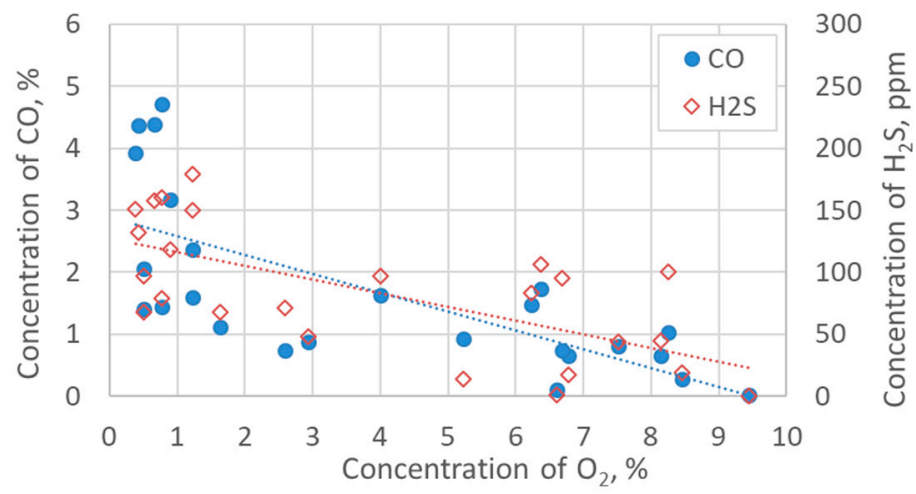

Figure 10. Comparison of average concentration values for six boiler operation variants and average corrosion rate in the tested boiler.

The presented example, shown in Figure 9, shows the differences in the maps of $\mathrm{O}_{2}$ and $\mathrm{CO}$ concentrations depending on the boiler operating parameters (on February 18th, the block power was $44 \mathrm{MW}$ and mills 2 and 3 worked; on February 23rd, the block power was $52.6 \mathrm{MW}$ and mills 1, 2, and 3 worked). In the case of this boiler, this is very important, because its operation is characterized by a large variability of performance. For this purpose, oxygen and carbon monoxide concentration measurements are required for many different boiler operating conditions (load, activity of mills, burner configurations, air distribution, etc.). Periodical measurements of the composition of the exhaust gas near the evaporator wall of the boiler were made for several variants of the boiler operating conditions (differing in load, working mills and burners, and air distribution), shown in Table 3. The number of measurement variants was limited due to the fact that, during the heating season, in the combined heat and power (CHP) plant, the authors had no influence on the possibility of changing the boiler capacity. The average results of six of these variants (variants no. 3-8, which were tested in 2016), are presented in Figure 10 as a comparison of the $\mathrm{O}_{2}$ concentration with the average corrosion rate. 
Table 3. Boiler operation during measuring of the flue gases composition in the boundary layer.

\begin{tabular}{|c|c|c|c|c|c|c|}
\hline $\begin{array}{l}\text { Measurement } \\
\text { Cases }\end{array}$ & Power MW & $\begin{array}{c}\text { Efficiency } \\
t / h\end{array}$ & $\begin{array}{c}\text { Working } \\
\text { Mills }\end{array}$ & $\begin{array}{l}\text { Total Air } \\
\mathrm{kNm}^{3} / \mathrm{h}\end{array}$ & $\begin{array}{l}\text { ROFA Air } \\
\mathrm{kNm}^{3} / \mathrm{h}\end{array}$ & $\begin{array}{c}\mathrm{NO}_{\mathrm{x}} \\
\mathrm{mg} / \mathrm{m}^{3}\end{array}$ \\
\hline Variant 1 & 52.9 & 227 & $1,2,3$ & 225 & 12,890 & 307 \\
\hline Variant 2 & 52.9 & 227 & 2,3 & 224 & 12,910 & 295 \\
\hline Variant 3 & 37.7 & 149 & 1,2 & 162 & 29,900 & 183 \\
\hline Variant 4 & 49.8 & 208 & $1,2,3$ & 220 & no data & 230 \\
\hline Variant 5 & 51.7 & 221 & $1,2,3$ & 193 & 29,200 & 278 \\
\hline Variant 6 & 29.0 & 129 & 1,2 & 135 & 26,940 & 398 \\
\hline Variant 7 & 33.5 & 147 & 2,3 & 137 & 29,200 & 243 \\
\hline Variant 8 & 50.3 & 224 & $1,2,3$ & 210 & 43,300 & 337 \\
\hline
\end{tabular}

As can be seen from the data shown in Figure 11, the relationship between the instantaneous flue gas composition (corresponding to constant boiler operation parameters), and the average corrosion rate, is characterized by a large spread of results, and the final result will be greatly influenced by the history of the boiler operation parameters. For oxygen concentration, the average values from long-term tests are usually significantly higher than the instantaneous values measured at full boiler capacity. It should be noted that the presented individual variants of the boiler's operation relate to several hours of measurements with constant boiler parameters, while the corrosion rate is, in this case, calculated in $\mathrm{nm} /$ hour for 17,566 working hours in the analyzed period (including planned and emergency boiler outages in this period).

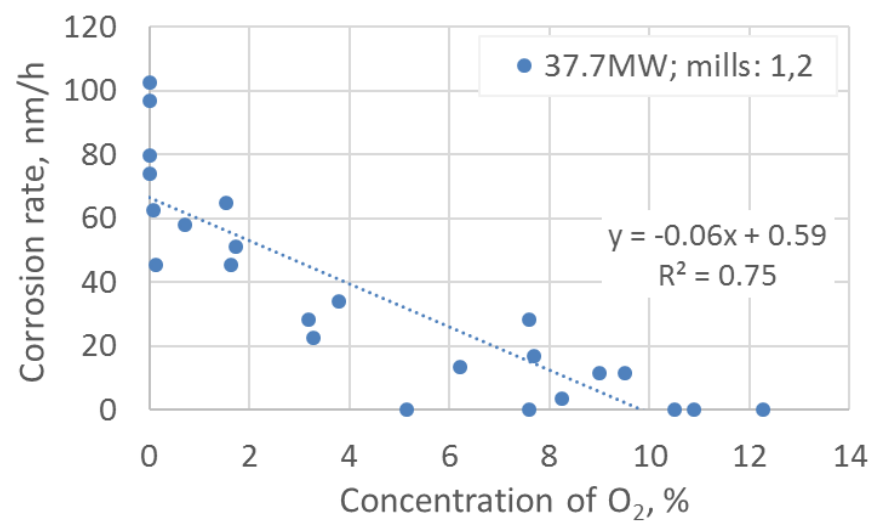

(a)

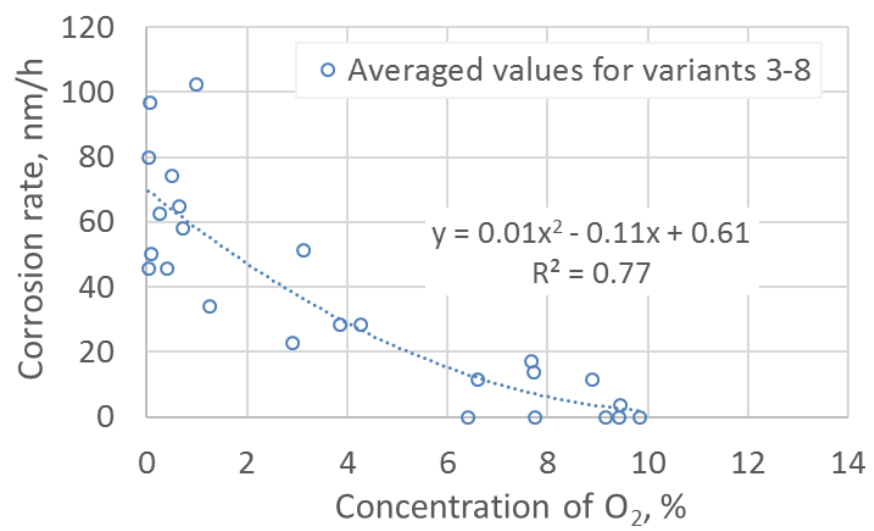

(b)

Figure 11. Correlation of the oxygen concentration measurement results in the boundary layer of the evaporator with the average corrosion rate determined from ultrasonic measurements: (a) one selected boiler operation option (Variant No.3), (b) averaged values for six boiler operation variants (Variants No. 3-8). 


\subsubsection{Continuous Measurements of $\mathrm{O}_{2}$ and $\mathrm{CO}$ Concentration near the Combustion Chamber Wall}

In order to achieve a good compromise between complexity and accuracy, it was decided to place five zirconium probes in preselected places on the boiler wall, shown in Figure 1. These locations were selected because they guaranteed the changeable level of oxygen concentration when boiler performance is changed (capacity, air flows, mills configuration). The CO concentration was also measured at these points. Based on the measurement results, the boiler operator can then decide to change the operating conditions while maintaining low $\mathrm{NO}_{\mathrm{x}}$ emissions. The monitoring system may appear useful when making decisions regarding protective air installations, investments in anti-corrosive coatings, or combustion process optimization activities.

The dedicated software (Rachel) allows us to average the measurement results from selected periods of the boiler operation time. Assuming the appropriate corrosion hazard criteria, depending on the concentrations of $\mathrm{O}_{2}$ and $\mathrm{CO}$ in the exhaust gas, the degree of corrosion risk of the water wall in the form of maps can be presented, both for instantaneous values and averaged values over a selected period. Figure 12 shows maps with average concentrations of $\mathrm{O}_{2}$ and $\mathrm{CO}$ from the six months of boiler operation and the corresponding corrosion risk map.

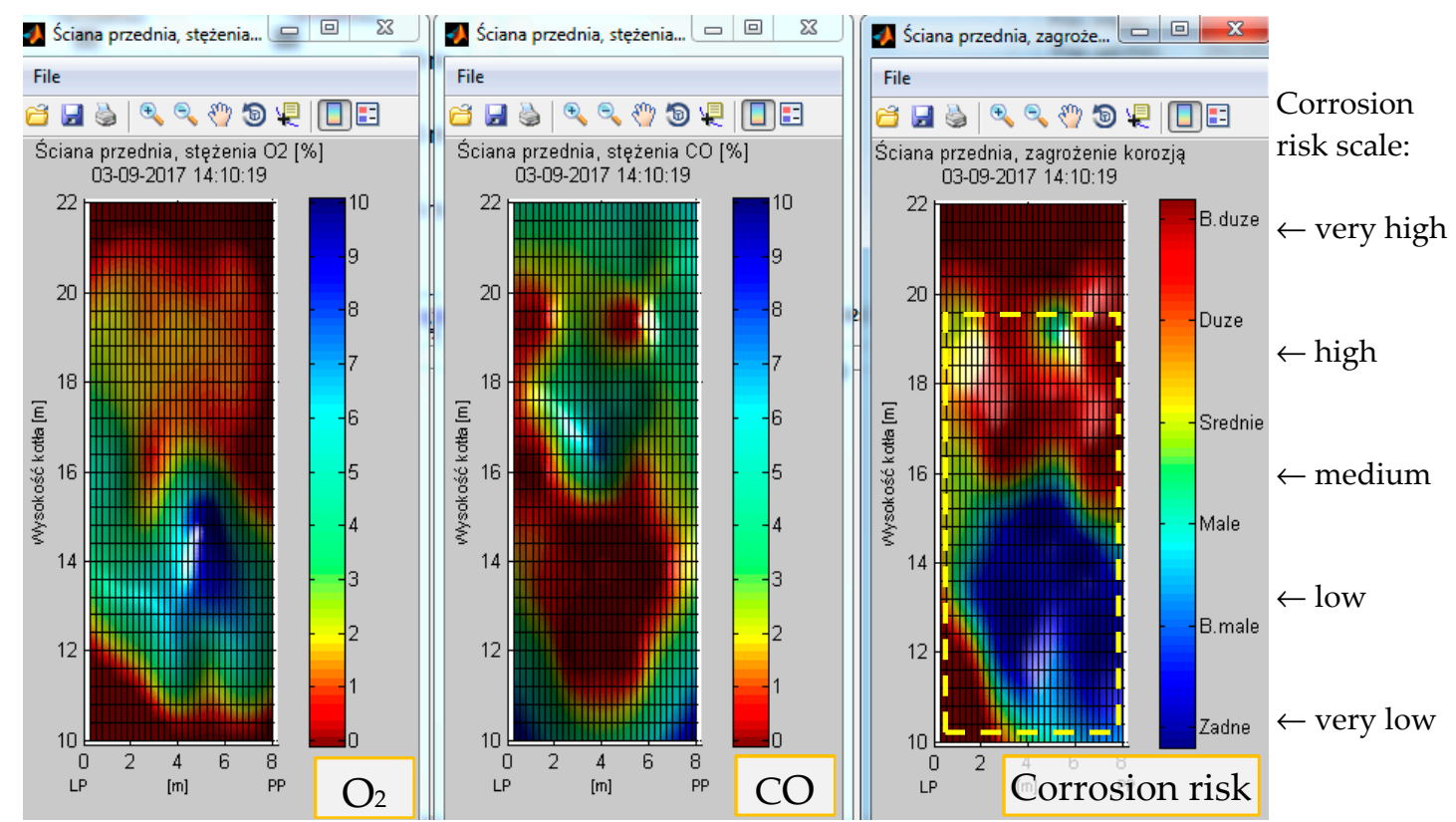

Figure 12. The maps of $\mathrm{O}_{2}, \mathrm{CO}$ concentration, and corrosion risk, generated by Rachel software from half year OP-230 boiler operation data [38]. The scale of the corrosion risk in this figure is the same as in Table 2-from none (blue color) up to very high (red color).

The corrosion hazard level, shown in Figure 12, indicates good compliance with the corrosion rate map developed based on ultrasonic measurements, as shown in Figure 7. The area of the corrosion risk map that was compared with the corrosion rate map is marked with a dotted yellow line in Figure 12. It should be noted, however, that the rate of corrosion was determined after a much longer time of boiler operation than the period of averaging the results of continuous measurements of exhaust gas composition. The monitoring of gas composition was carried out for a longer period than one year, but in the meantime, the measuring installation was modernized, and it was decided to take into account only the time during which the system worked without breaks and failures. In contrast, the determination of the average corrosion rate, based on the ultrasonic measurements in this boiler, was possible only during outages of the boiler, planned earlier by the operator. 
4.2.3. Determination of Corrosion Rate Based on Measurements of $\mathrm{O}_{2}$ and CO Concentrations in the Boundary Layer of the Combustion Chamber

Data representing the loss of water wall tube thickness in the long-term operation of the boiler were used to determine the corrosion rate $(\mathrm{nm} / \mathrm{h})$, taking into account the boiler's operating hours during that period. To define the correlation between the corrosion rate and $\mathrm{O}_{2} / \mathrm{CO}$ concentrations, the averages over six months of operation maps of $\mathrm{O}_{2}$ and $\mathrm{CO}$ concentrations, generated by artificial neural networks and a map of the wall thickness loss of the evaporator tubes based on the ultrasonic technique, were analyzed. The test procedure is shown schematically in Figure 13 and the results of the analysis are shown in Figures 14-16. The comparison was made for almost 200 points, where $\mathrm{O}_{2}$ and $\mathrm{CO}$ concentrations at these points were calculated using neuronal networks. It can be seen that spots of high corrosion rates correspond with low $\mathrm{O}_{2}$ levels and high $\mathrm{CO}$ levels.

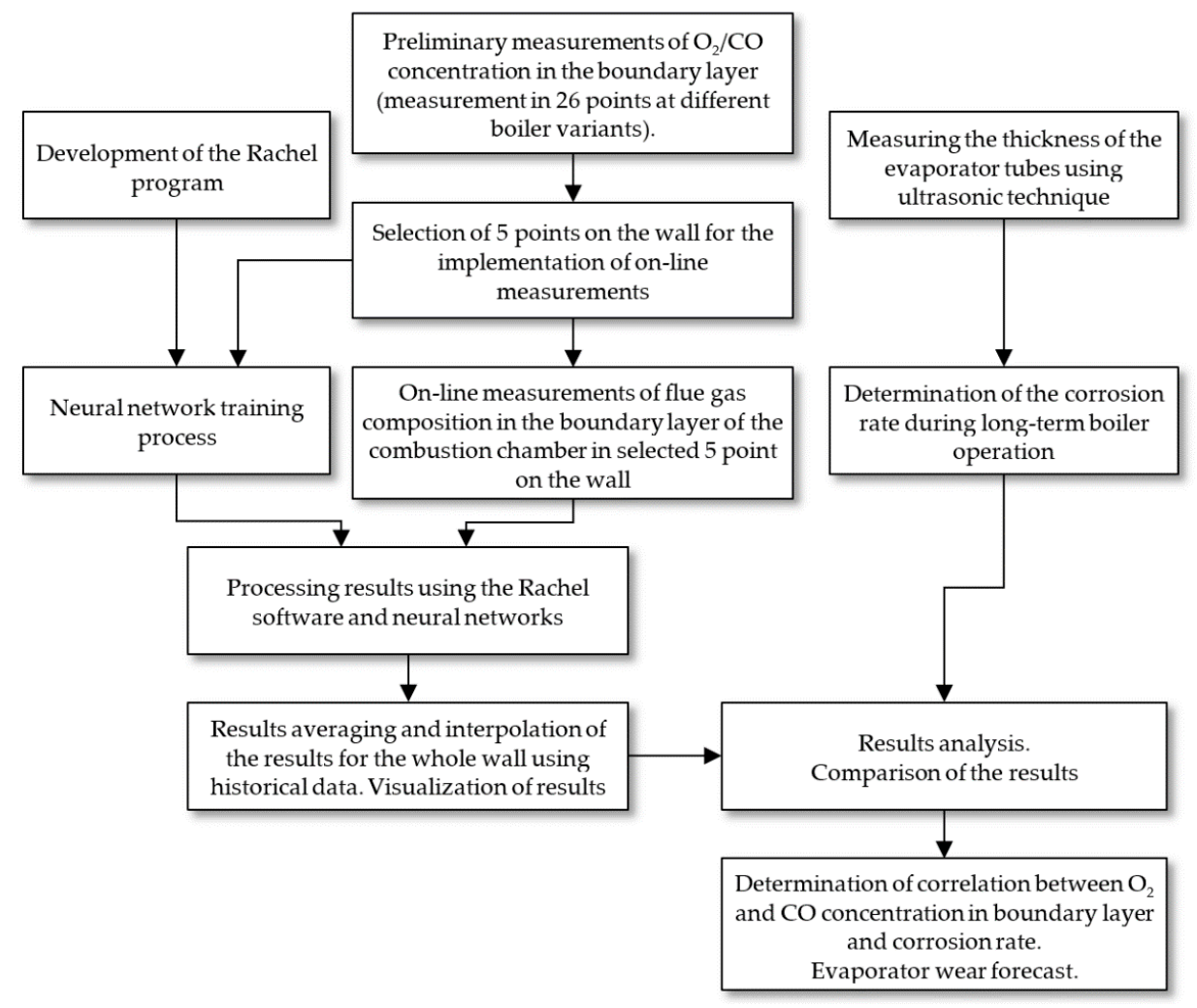

Figure 13. The diagram of the testing procedure to determine the correlation between flue gas composition and the corrosion rate of the evaporator.

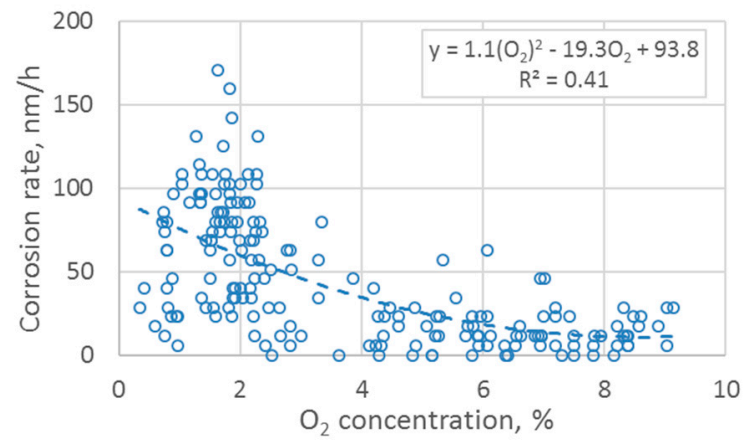

(a)

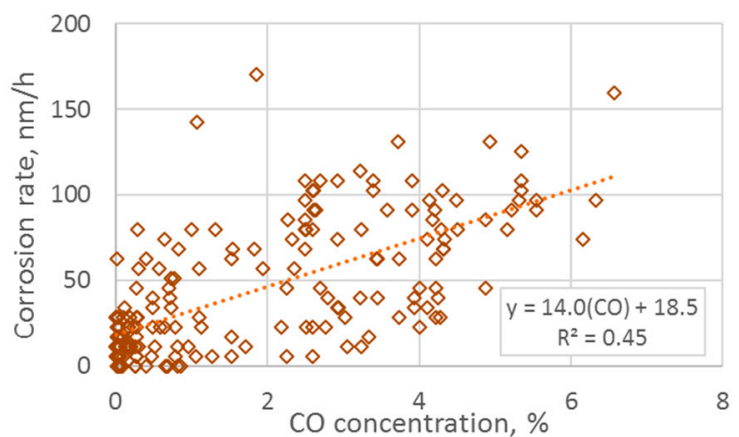

(b)

Figure 14. Dependence of corrosion rate $(\mathrm{nm} / \mathrm{h})$ on $\mathrm{O}_{2}$ and $\mathrm{CO}$ concentration $((\mathbf{a}, \mathbf{b})$, respectively) in the boundary layer of the combustion chamber. 


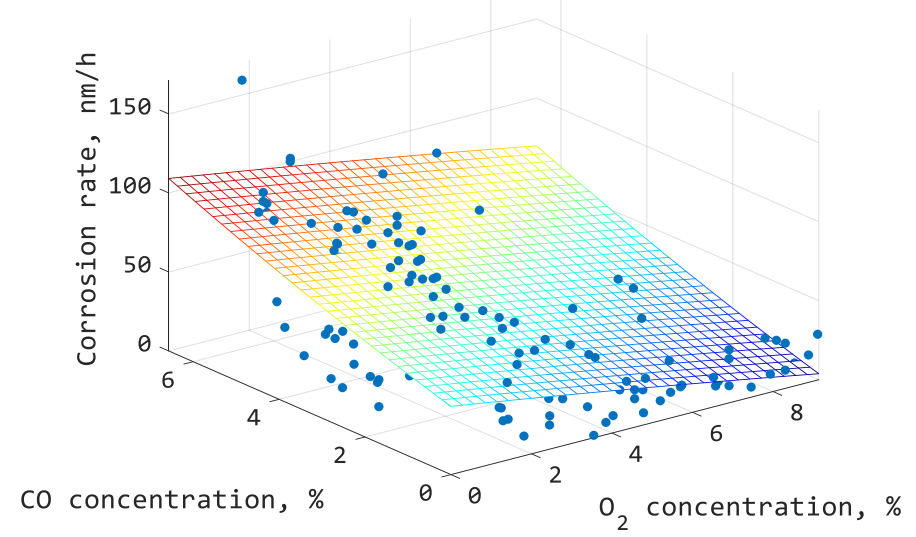

Figure 15. Correlation between $\mathrm{O}_{2}$ and $\mathrm{CO}$ concentration and the corrosion rate of the evaporator tubes, determined based on ultrasonic measurements.

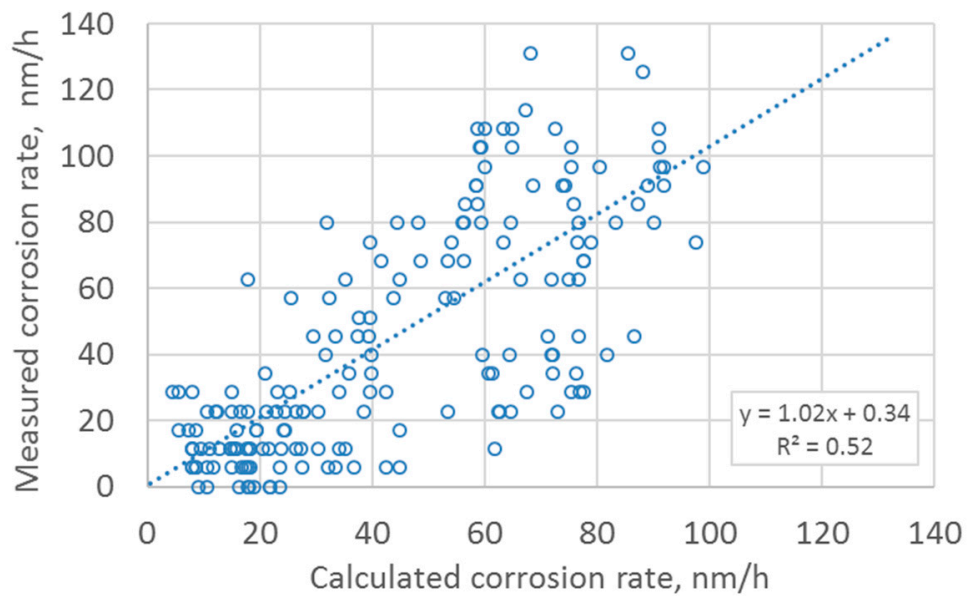

Figure 16. Comparison of the corrosion rate obtained based on calculations and measurements.

The graphs visibly show the increase in the corrosive dynamic with decreasing oxygen content and increasing $\mathrm{CO}$ content taken from historical data. The corrosion rate can be interrelated with oxygen concentration using the following formula:

$$
\mathrm{w}_{\mathrm{cor}}=1.1 \cdot\left(\mathrm{O}_{2}\right)^{2}-19.3 \cdot \mathrm{O}_{2}+93.8(\mathrm{~nm} / \mathrm{h})
$$

and with carbon monoxide concentration with the formula:

$$
\mathrm{w}_{\mathrm{cor}}=14.0 \cdot \mathrm{CO}+18.5(\mathrm{~nm} / \mathrm{y})
$$

By comparing both of the above characteristics, the effect of the $\mathrm{O}_{2}$ and $\mathrm{CO}$ levels on the corrosion rate can be presented simultaneously, as in Figure 15.

Taking into account the above results, the corrosion rate can be interrelated with oxygen and $\mathrm{CO}$ concentrations using the following formula:

$$
\mathrm{w}_{\text {cor }}=-0.04 \cdot\left(\mathrm{O}_{2}\right)^{2}-3.94 \mathrm{O}_{2}+0.28 \cdot \mathrm{CO}^{2}+8.21 \cdot \mathrm{CO}+43.17(\mathrm{~nm} / \mathrm{h})
$$

The coefficients of Equations (2)-(4) were determined using the least-squares method. For this purpose, only data from the boiler area located between the measurements points No. 1-26 were used (i.e., data from the inside the convex polygon whose vertices were the following measuring locations: $1,2,6,13,18,26,25,24,23,22,17,9,3)$, as shown in Figure 6. This is because, inside this area, neural networks are particularly good at predicting $\mathrm{O}_{2}$ and $\mathrm{CO}$ concentrations. The $\mathrm{O}_{2}$ and $\mathrm{CO}$ concentration 
values were averaged over time. Linear interpolation was used to determine the average $\mathrm{O}_{2}$ and $\mathrm{CO}$ concentrations in the same locations where corrosion rate was measured.

Assuming the above Equation (4), the corrosion rate was calculated based on the average (semi-annual) values of $\mathrm{O}_{2}$ and $\mathrm{CO}$ concentration. In this way, the relationship between the value calculated from Equation (4) and the measured corrosion rate was determined. A considerable dispersion of values is visible on the graph. However, the proposed trend line indicates quite good agreement with the measurement results, shown in Figure 16.

Analyzing the results presented in Figure 16, it should be noted that the online registration period of the flue gas composition in the boundary layer of the combustion chamber, for which the calculated corrosion rate was determined, does not coincide exactly with the period for which the measured corrosion rate was determined. In the analyzed case, the recording time of the flue gas composition on-site measurement covered only about $20 \%$ of the boiler operation time, which may be the reason for additional uncertainty related to the history of the boiler operating conditions.

\section{Conclusions}

A simple tool for the continuous control of the corrosion hazard in PC boilers has been developed and tested. One of the most important advantages of the proposed monitoring system is the simplicity of the measuring system. The simplification of this system was possible due to the use of neural networks. This allowed for simplified measurements of the exhaust gas composition in the boundary layer of the combustion chamber at only a few selected points, and then the determination of results on the entire wall. By carrying out continuous measurements of $\mathrm{O}_{2}$ and $\mathrm{CO}$, using historical data on the operating conditions of the boiler, and formulating equations for the corrosion rate for the tested boiler, it is possible to make a quick corrosion risk assessment and forecast future wear on evaporator tubes. This, in turn, is very important information for boiler service teams, which may plan outage times, avoiding unexpected and costly failures. It can also be used for periodic boiler operation optimization.

Author Contributions: Conceptualization, T.H.; methodology, T.H. and S.K.; software, S.K.; validation, T.H., S.K., and K.H.; formal analysis, T.H., S.K., K.H., and K.M., T.J.; investigation, T.H., K.M., and T.J.; resources, T.H. and K.M.; writing-review and editing, T.H., S.K., K.M., and K.H., T.J.; visualisation, T.H., K.H., and S.K.; funding acquisition T.H. and T.J. All authors have read and agreed to the published version of the manuscript.

Funding: This work was supported by EDF Polska (agreement No C17Z160045) and Wroclaw University of Science and Technology Statutory Research Found.

Acknowledgments: The author would like to thank their colleagues from Thomex company for their help and technical support in measuring system development.

Conflicts of Interest: The authors declare no conflict of interest.

\section{References}

1. Bryers, R.W. Fireside slagging, fouling, and high-temperature corrosion of heat-transfer surface due to impurities in steam-raising fuels. Prog. Energy Combust. Sci. 1996, 22, 29-120. [CrossRef]

2. Harb, J.; Smith, E. Fireside corrosion in pc-fired boilers. Prog. Energy Combust. Sci. 1990, 16, $169-190$. [CrossRef]

3. Pronobis, M. Modernization of Power Boilers; WNT: Warszawa, Poland, 2001. (In Polish)

4. Karlsson, S.; Amand, L.-E.; Liske, J. Reducing high-temperature corrosion on high-alloyed stainless steel superheaters by co-combustion of municipal sewage sludge in a fluidised bed boiler. Fuel 2015, 139, 482-493. [CrossRef]

5. Kordylewski, W.; Mościcki, K.J.; Witkowski, K.J. Lab-Scale Investigations During Combustion of Agricultural Residues and Selected Polish Coals. Chem. Process. Eng. 2014, 35, 249-262. [CrossRef]

6. Chandrappa, K.G.; Venkatesha, T.V. Electrochemical bulk synthesis of Fe3O4and $\alpha$-Fe2O3nanoparticles and its $\mathrm{ZnCo} \alpha \mathrm{Fe} 2 \mathrm{O} 3 \mathrm{composite}$ thin films for corrosion protection. Mater. Corros. 2012, 65, 509-521. [CrossRef]

7. Adamiec, J. High temperature corrosion of power boiler components cladded with nickel alloys. Mater. Charact. 2009, 60, 1093-1099. [CrossRef] 
8. Modliński, N.J. Computational Modelling of a Tangentially Fired Boiler With Deposit Formation Phenomena. Chem. Process. Eng. 2014, 35, 361-368. [CrossRef]

9. Ma, Z.; Iman, F.; Lu, P.; Sears, R.; Kong, L.; Rokanuzzaman, A.; McCollor, D.P.; Benson, S.A. A comprehensive slagging and fouling prediction tool for coal-fired boilers and its validation/application. Fuel Process. Technol. 2007, 88, 1035-1043. [CrossRef]

10. Hernik, B. Numerical Research of the Modification of the Combustion System in the OP 650 Boiler. Energies 2020, 13, 725. [CrossRef]

11. Yang, W.; You, R.; Wang, Z.; Zhang, H.; Zhou, Z.; Zhou, J.; Guan, J.; Qiu, L. Effects of Near-Wall Air Application in a Pulverized-Coal 300 MWe Utility Boiler on Combustion and Corrosive Gases. Energy Fuels 2017, 31, 10075-10081. [CrossRef]

12. Mabbutt, S.; Simms, N.; Oakey, J. High temperature corrosion monitoring by electrochemical noise techniques. Corros. Eng. Sci. Technol. 2009, 44, 186-195. [CrossRef]

13. Schettler, D.; Hubner, K.; Gorner, K. On-line monitoring of high-temperature corrosion from superheater materials. VGB PowerTech 2003, 6, 94-98.

14. Kuang, F.; Jinna, J.; Zou, C.; Shi, T.; Wang, Y.; Zhang, S.; Xu, H.; Zhang, J. Electrochemical Methods for Corrosion Monitoring: A Survey of Recent Patents !2009-10-01 !2009-11-25 !2010-02-18 ! Recent Pat. Corros. Sci. 2010, 2, 34-39. [CrossRef]

15. Leino, T.J.; Aho, M.J.; Gynther, S.J.; Ruuskanen, T.A.; Häkkinen, M.H. Experiences from a Novel Sensor for Fireside Corrosion Monitoring during Grate Combustion of Corn Stover/Wood Chip Blends. Energy Fuels 2013, 27, 5653-5662. [CrossRef]

16. Retschitzegger, S.; Gruber, T.; Brunner, T.; Obernberger, I. Short term online corrosion measurements in biomass fired boilers. Part 1: Application of a newly developed mass loss probe. Fuel Process. Technol. 2015, 137, 148-156. [CrossRef]

17. Shim, H.-S.; Valentine, J.R.; Davis, K.; Seo, S.-I.; Kim, T.-H. Development of fireside waterwall corrosion correlations using pilot-scale test furnace. Fuel 2008, 87, 3353-3361. [CrossRef]

18. Pronobis, M.; Hernik, B.; Wejkowski, R. Kinetics of low NOx corrosion of waterwalls in utility boilers. Rynek Energii 2010, 6, 121-128.

19. Bukowski, P.; Hardy, T.; Kordylewski, W. Evaluation of corrosion hazard in PF boilers applying the oxygen content in flue gases. Arch. Combust. 2009, 29, 11-18.

20. Zheng, S.; Yang, Y.; Li, X.; Liu, H.; Yan, W.; Sui, R.; Lu, Q. Temperature and emissivity measurements from combustion of pine wood, rice husk and fir wood using flame emission spectrum. Fuel Process. Technol. 2020, 204, 106423. [CrossRef]

21. Ebert, V.; Teichert, H.; Strauch, P.; Kolb, T.; Seifert, H.; Wolfrum, J. Sensitive in situ detection of CO and O2 in a rotary kiln-based hazardous waste incinerator using $760 \mathrm{~nm}$ and new $2.3 \mu \mathrm{m}$ diode lasers. Proc. Combust. Inst. 2005, 30, 1611-1618. [CrossRef]

22. Rodríguez, F.; Tova, E.; Cortés, V.; Cañadas, L. OPTICOM: Advanced automatic monitoring system of local combustion conditions for improving boiler performance in PC power plants. Fuel 2002, 81, 637-645. [CrossRef]

23. Ostrowski, P.; Kalisz, S.; Wejkowski, R. Investigations of low NOx corrosion hazards in boiler OP650 of the Rybnik power plant using a mobile monitoring system. Rynek Energii 2011, 3, 161-165.

24. Kalogirou, S. Artificial intelligence for the modeling and control of combustion processes: A review. Prog. Energy Combust. Sci. 2003, 29, 515-566. [CrossRef]

25. Abbas, T.; Awais, M.; Lockwood, F. An artificial intelligence treatment of devolatilization for pulverized coal and biomass in co-fired flames. Combust. Flame 2003, 132, 305-318. [CrossRef]

26. Zhu, Q.; Jones, J.M.; Williams, A.; Thomas, K.M. The predictions of coal/char combustion rate using ANN approach. Fuel 1999, 78, 1755-1762. [CrossRef]

27. Yin, C.; Luo, Z.; Zhou, J.; Cen, K. A Novel Non-Linear Programming-Based Coal Blending Technology for Power Plants. Chem. Eng. Res. Des. 2000, 78, 118-124. [CrossRef]

28. Bunsan, S.; Chen, W.-Y.; Chen, H.W.; Chuang, Y.-H.; Grisdanurak, N. Modeling the dioxin emission of a municipal solid waste incinerator using neural networks. Chemosphere 2013, 92, 258-264. [CrossRef]

29. Tan, C.-K.; Wilcox, S.J.; Ward, J.; LeWitt, M. Monitoring near burner slag deposition with a hybrid neural network system. Meas. Sci. Technol. 2003, 14, 1137-1145. [CrossRef] 
30. Pena, B.; Teruel, E.; Diez, L. Soft-computing models for soot-blowing optimization in coal-fired utility boilers. Appl. Soft Comput. 2011, 11, 1657-1668. [CrossRef]

31. Kamrunnahar, M.; Urquidi-Macdonald, M. Prediction of corrosion behaviour of Alloy 22 using neural network as a data mining tool. Corros. Sci. 2011, 53, 961-967. [CrossRef]

32. Haque, M.E.; Sudhakar, K.V. Prediction of corrosion-fatigue behavior of DP steel through artificial neural network. Int. J. Fatigue 2001, 23, 1-4. [CrossRef]

33. Cai, J.; Cottis, R.; Lyon, S. Phenomenological modelling of atmospheric corrosion using an artificial neural network. Corros. Sci. 1999, 41, 2001-2030. [CrossRef]

34. Xiaomin, M. Recognition of Toxic Gases Emission in Power Plant Based on Artificial Neural Network. Energy Procedia 2012, 17, 1578-1584. [CrossRef]

35. Ozmen, A.; Tekce, F.; Ebeoğlu, M.; Taşaltın, C.; Öztürk, Z.; Tasaltin, C. Finding the composition of gas mixtures by a phthalocyanine-coated QCM sensor array and an artificial neural network. Sens. Actuators $B$ Chem. 2006, 115, 450-454. [CrossRef]

36. Kakietek, S.; Hardy, T.; Golec, T.; Kordylewski, W. the Neural networks and genetic algorithms as a tool for monitoring of low emission corrosion and optimization of utility boiler performance. In Proceedings of the Tenth International Conference on Energy for a Clean Environment, Clean Air 2009, Lisbon, Portugal, 7-9 July 2009.

37. Wejkowski, R.; Kalisz, S.; Hardy, T.; Sarapata, B.; Kubiczek, H.; Janda, T. The Control of High Temperature Corrosion Phenomenon in Boundary Layer Using Different Measurement Methods; Taller, J., Ed.; Modern Energy Technologies, Systems and Units: Kraków, Poland, 2013.

38. Hardy, T.; Kakietek, S.; Janda, T. A tool for on-line control of high-temperature corrosion hazard on steam boilers. Arch. Combust. 2017, 37, 107-118.

39. Kakietek, S.; Andryjowicz Cz Sokolik, K.; Maciejewski, J.; Hardy, T.; Golec, T. The on-line system for monitoring of low emission corrosion of water walls in the case of boiler no 5 in Belchatow Power Plant. In Proceedings of the 12th International Conference on Boiler Technology ICTB'2014, Szczyrk, Poland, 21-24 October 2014.

40. Davis, C.J.; James, P.J.; Pinder, L.W. Fireside Corrosion in Pulverized-Coal-Fired Boilers: Effect of Coal Chlorine and Combustion Parameters; EPRI: Palo Alto, CA, USA, 2001.

41. Bakker, W. Waterwall Wastage in Low NOx Boilers: Root Causes and Remedies; EPRI: Palo Alto, CA, USA, 1998.

42. Nava, J.C.; Henry, J. Materials degradation mechanisms in coal-fired boilers. Mater. High Temp. 2003, 20, 55-60. [CrossRef]

43. Bakker, W.T. The effect of deposits on waterwall corrosion in fossil fueled boilers. Mater. High Temp. 2003, 20, 161-168. [CrossRef]

44. Gruber, T.; Schulze, K.; Scharler, R.; Obernberger, I. Investigation of the corrosion behaviour of 13CrMo4-5 for biomass fired boilers with coupled online corrosion and deposit probe measurements. Fuel 2015, 144, 15-24. [CrossRef]

45. Stein-Brzozowska, G.; Norling, R.; Viklund, P.; Maier, J.; Scheffknecht, G. Fireside Corrosion during Oxyfuel Combustion Considering Various SO2 Contents. Energy Procedia 2014, 51, 135-147. [CrossRef]

46. Paz, M.; Zhao, D.; Karlsson, S.; Liske, J.; Jonsson, T. Investigating corrosion memory: The influence of previous boiler operation on current corrosion rate. Fuel Process. Technol. 2017, 156, 348-356. [CrossRef]

47. Modlinski, N.; Hardy, T. Development of high-temperature corrosion risk monitoring system in pulverized coal boilers based on reducing conditions identification and CFD simulations. Appl. Energy 2017, 204, 1124-1137. [CrossRef]

48. Kakietek, S.; Andryjowicz Cz Sokolik, K.; Jagiełło, K.; Baran, A. Optimization of the BB-1150 t/h boiler operation with the use of the system to control the risk of low oxygen corrosion of the boiler evaporator (in Polish). In Proceedings of the 13th International Conference Thermal Power Plants, Słok, Poland, 31 May-2 June 2017.

(C) 2020 by the authors. Licensee MDPI, Basel, Switzerland. This article is an open access article distributed under the terms and conditions of the Creative Commons Attribution (CC BY) license (http://creativecommons.org/licenses/by/4.0/). 